ARTIKEL

Filsafat Politik Nurcholish Madjid

Muhammad Saleh Tajuddin

Kedaulatan Rakyat dalam Pemikiran Filsafat

Politik Montesquieu

Fajrul Ilmy Darussalam \& Andi Batara Indra

$189-204$

Politik Multikulturalisme: Sebuah Gerakan Keadilan

dan Kesetaraan

Muhaemin Latif

$205-229$

Kompetisi, Kompromi dan Coalition Agreement: Berebut

Kursi Wakil Gubernur DKI Jakarta di Tengah

Kontestasi Pemilihan Presiden 2019

Mahpudin \& Fransisca Mega Lestari

$230-259$

Kegagalan Keterlibatan Politik: Dari Kesenjangan Digital

Menuju Kesenjangan Demokrasi

Fairuz Arta Abhipraya \& Bambang Eka Cahya Widodo

Mobilisasi Massa Kemenangan Kolom Kosong Pada Pemilihan Walikota Makassar Tahun 2018

Gustiana Kambo

Kinerja Komisi Pemilihan Umum Kota Makassar dalam

Melindungi Hak Pilih Warga di Tengah

Pandemi COVID-19

Dyahwanti Sulistyowati, Muhammad, Sukri \& Ariana

Isu Pemekaran Wilayah Sebagai Komoditas Politik Dalam Masyarakat

To Pulo di Kepulauan Selayar

Dwi Indriani \& Sudarmono

Penanganan Konflik Melalui Keamanan di Kalimantan Barat 


\title{
FILSAFAT POLITIK NURCHOLISH MADJID
}

\author{
Muhammad Saleh Tajuddin \\ UIN Alauddin Makassar \\ Email: saleh.tajuddin@uin-alauddin.ac.id
}

\begin{abstract}
Abstrak
Tulisan ini membahas tentang filsafat politik Nurcholish Madjid. Ia adalah pemikir Islam kontemporer yang memiliki pengaruh kuat di kalangan pemikir muda di Indonesia. Tujuan tulisan ini adalah untuk mengungkapkan filsafat politik Islam Nurcholish Madjid, terkait dengan konsep civil society dan sekularisasi. Tulisan ini menggunakan library research dengan jenis penulisan qualitatif. Data-data dikumpulkan melalui perpustakaan berupa buku-buku teks dan jurnal ilmiah. Pendekatan yang dilakukan adalah filsafat dan politik dengan analisis deskriptif. Hasil yang diperoleh dalam tulisan ini adalah bahwa ide Nurcholish Madjid tentang civil society didasarkan atas masyarakat Islam yang dibangun oleh Nabi Muhammad di kota Madinah pada tahun $570 \mathrm{M}$. Civil society diterjemahkan dengan istilah "masyarakat madani," meliputi aspek egalitarian, respek kepada orang lain, berpartisipasi aktif dalam masyarakat, berpegang kepada hukum dan keadilan, toleransi dan pluralisme, dan deliberasi. Dalam menggulirkan filsafat sekularisasinya, Nurcholish mencari justifikasi dari ajaran-ajaran Islam melalui dua kalimat syahadat, bahwa manusia bebas dari berbagai jenis kepercayaan kepada tuhan-tuhan yang selama ini dianut, kemudian mengukuhkan kepercayaan kepada Tuhan yang sebenarnya.
\end{abstract}

\section{Kata Kunci:}

Filsafat Politik, Civil Society, Masyarakat Madani, Sekularisasi

\begin{abstract}
The research emphasized the political philosophy of Nurcholish Madjid, a contemporary Islamic scholar, who had a strong influence among the young scholars in Indonesia. The study aims to describe the philosophy of Islamic politics by Nurcholish Madjid particularly the concept of secularization and civil society. By using qualitative data, particularly the library research method through books and academic journal, the study resulted the idea of civil society had a root from Islamic citizen which was built by Prophet Muhammad SAW in Madina, 570 C. The civil society was translated into the term "Masyarakat Madani" which including some aspects: egality, respect to others, actively participating in the society, rely on law and justice, tolerance and pluralism, and deliberation. In order to explain his secularization philosophy, Nurcholish gave a justification from Islamic teaching through confession of faith (syahada), which told that people were free from various beliefs, then strengthen their belief to the real God.
\end{abstract}

\section{Keywords:}

Political Philosophy, Civil Society, Masyarakat Madani, Secularization 


\section{Pendahuluan}

Terjadinya reformasi Islam di abad ke-20 memunculan berbagai gerakan sosial melintasi dunia Islam sebagai akibat dari kontribusi para intelektual Muslim dengan ideide mereka yang cukup kontroversial. Misalnya Maulana Maududi, Ayatollah Rohullah Khomeini, Sayid Qutb, Abdullah Azzam, dan Osama bin Laden, di mana karya mereka seluruhnya dipandang sebagai bacaan esensial di dalam memahami pemikiran Islam. Padahal pemikiran mereka menampilkan sisi pemikiran Islam fundamental. Sementara itu, karya-karya dan pemikiran reformis Islam yang menampilkan wajah Islam yang santun dan toleran seperti Nurcholish Madjid di Indonesia justru sering dilupakan.

Nurcholish Madjid adalah pemikir Islam kontemporer akhir abad ke-20 di Indonesia. Nurcholish Madjid melihat Islam memiliki ajaran tentang prinsip-prinsip kemanusiaan universal sehingga mampu merespon persoalan kemanusiaan, termasuk aspek filsafat politik. ${ }^{1}$ Ia memiliki pengaruh yang sangat besar di Indonesia. Pemikiran Nurcholish Madjid yang digulirkan mendapat pengaruh besar bagi generasi muda Islam di Indonesia dalam melakukan pembaharuan pemikiran Islam dengan berbagai tantangan yang dihadapinya. Meskipun Nurcholish Madjid sudah meninggal, pemikiran-pemikirannya yang kontroversi masih tetap digulirkan dan menjadi wacana pemikiran yang terus menggelinding dalam diskusi-diskusi formal maupun non-formal.

Tujuan tulisan ini adalah untuk mengungkapkan filsafat politik Nurcholish Madjid, khususnya tentang aspek civil society dan sekularisasi. Tulisan ini menggunakan library research dengan jenis penulisan kualitatif. Data-data dikumpulkan melalui perpustakaan berupa buku dan jurnal ilmiah. Pendekatan yang dilakukan adalah filsafat dan politik dengan analisis deskriptif.

Mengawali tulisan ini, penulis mencoba memperkenalkan riwayat hidup dan corak pemikiran Nurcholish Madjid. Selanjutnya akan dijelaskan pemikiran pemikiran Nurcholish Madjid tentang sekularisasi dan civil society.

\section{Kehidupan dan Corak Pemikiran Nurcholish Madjid}

\section{Latar Belakang Kehidupan}

${ }^{1}$ Sulbi, "Islam Kemodernan dan Keadilan Sosial dalam Pandangan Nurcholish Madjid" dalam Palita: Journal of Social Religion Research, Vol. 6, No. 1 (2021), h. 1-24. 
Salah satu aspek penting untuk dicatat dalam kaitannya dengan kontribusi pemikiran Nurcholish Madjid terhadap pemikiran Islam di Indonesia adalah latar belakang kehidupannya. Ia lahir di Jombang, Jawa Timur pada tanggal 17 Maret 1939. Dia belajar di Sekolah Dasar di pagi hari dan belajar Ibtidaiyah di sore hari. Dia belajar di Pesantren Tradisional Darul 'Ulum di Rejoso dan Pesantren Modern Darussalam di Gontor, Ponorogo. Nurcholish menyelesaikan Sarjana (S1) pada Fakultas Adab IAIN Syarif Hidayatullah Jakarta pada tahun 1968. Dia melanjutkan program doktor (S3) dalam bidang studi pemikiran Islam di University of Chicago tahun 1984. Selama kuliah, ia aktif pada gerakan-gerakan mahasiswa, di antaranya Himpunan Mahasiswa Islam menjabat sebagai Ketua Umum Pengurus Besar HMI selama dua periode (19661969 dan 1969-1971). Dia juga aktif sebagai Presiden PEMINAT (Moslem Association of Southeast Asia) antara 1967 dan 1969, dan sebagai Wakil Presiden IIFSO (International Islamic Federation of Students Organizations, antara 1969 dan 1971). Pada tahun 1993, ia aktif sebagai anggota Komite Nasional HAM, juga sebagai anggota Lembaga Penelitian Nasional pada tahun 1994, dan sebagai anggota dan penasehat ICMI sejak 1995. Nurcholish Madjid meninggal pada tanggal 29 Agustus 2005 di Jakarta.

\section{Corak Pemikiran}

Sebuah pertanyaan yang sering muncul adalah berkaitan dengan corak pemikiran Nurcholish Madjid, apakah ia dikategorikan sebagai neo-modernis atau neotradisionalis? Sangat jelas pemikiran Nurcholish Madjid dikategorikan sebagai sosok intelektual yang bercorak modernis Islam, meskipun mayoritas mengatakan sebagai neo-modernis. Argumen ini muncul pada tahun 1970-an ketika idenya muncul sebagai "shock therapy" agar masyarakat Islam di Indonesia tertantang untuk berpartisipasi dalam pembangunan dan modernisasi. Sementara itu, sarjana muslim lainnya cenderung berargumentasi bahwa corak pemikiran Nurcholish Madjid adalah lebih sesuai dengan neo-tradisionalis. Ide ini muncul ketika ia melontarkan ide-ide pemikirannya setelah kembali dari Chicago. Terlepas dari perdebatan tersebut, seluruh sumber literatur setuju bahwa pemikiran Nurcholish Madjid adalah sebuah paradigma baru pemikiran Islam di 
Indonesia, sebab ia mencari bentuk untuk mengkompromikan ide-ide pemikiran modernis dan tradisionalis. ${ }^{2}$

Greg Barton mendefinisikan Islam neo-modernis sebagai sebuah gerakan baru dalam pemikiran Islam yang mengkombinasikan ide-ide liberal yang progresif dengan elemen-elemen fundamental dalam ajaran Islam. Barton mendefinisikan neomodernisme Islam sebagai "a new movement in Islamic thought that combines progressive liberal ideas with the essential elements of Islamic teaching. Islamic neomodernism is different from Islamic modernism or classical modernism in relation to the new approach in ijtihad". ${ }^{3}$

Ada beberapa Islam neo-modernis di Indonesia yang merupakan pemuka intelektual muslim, di antaranya Nurcholish Madjid, Djohan Effendi, Ahmad Wahid, dan Abdurrahman Wahid. Mereka mencoba mencari sebuah interpretasi baru terhadap khazanah ilmu pengetahuan klasik dengan menggunakan metode analisis Barat. ${ }^{4}$

Menurut Fachry Ali dan Bahtiar Effendy, munculnya pemikiran neo-modernis adalah berkaitan dengan sejarah peradaban Islam. Islam modernis muncul sebagai sebuah kekuatan sosial di awal abad ke-20, namun mereka gagal mempertahankan ideide modernis saat organisasi Muhamadiyah tumbuh menjadi besar. Ideologi modernis didasarkan atas gerakan melalui institusi-institusi modern. Misalnya, modernis Islam mengkonsentrasikan untuk mendefinisikan tugas-tugas keagamaan secara tekstual. Ajaran Islam harus memurnikan elemen-elemen yang dapat menyebabkan bid'ah, takhayul dan khurafat. Anjuran untuk kembali kepada Al-Quran dan hadis nampaknya Islam modernis diidentifikasikan sebagai fundamentalis Islam. Sementara itu, Islam

\footnotetext{
${ }^{2}$ Sudah diketahui dalam sejarah bahwa ada dua ideologi Islam di Indonesia yang saling kontraversi, yaitu Muhammadiyah disimbolkan sebagai Islam modernis dan Nahdlatul Ulama (NU) sebagai Islam tradisionalis. Sementara itu, Islam neo-modernis adalah sebuah paradigma baru yang mencoba menjembatani kedua ideologi tersebut. Fachry Ali dan Bachtiar Effendy mengatakan bahwa neo-modernis adalah sebuah prodak baru yang mencoba menyelesaikan permasalahan kedua ideologi besar di Indonesia, yaitu modernis dan tradisionalis. Perbedaan esensial antara neo-modernis dengan kedua ideologi tersebut adalah kemampuan untuk mengakomodasi ide pemikiran modern dengan tradisional. Lihat Fachry Ali \& Bachtiar Effendy, Merambah Jalan Baru Islam: Rekonstruksi Pemikiran Islam Indonesia Masa Orde Baru (Bandung: Mizan, 1990), h. 175.

${ }^{3}$ Dalam ajaran Islam ada tiga sumber hukum, yaitu Al-Quran, hadis, dan ijtihad. Jika seseorang menemukan problem maka mereka mencari jawabannya dalam Al-Quran dan hadis, dan jika tidak ditemukan, mereka memutuskan untuk menginterpretasikan kedua sumber tersebut berdasarkan nalar. Jika seseorang melakukan kesalahan dalam menginterpretasi, maka ia akan mendapat pahala satu, dan jika ia benar dalam melakukan interpretasi maka ia mendapat pahala dua. Neo-modernis mengaktualisasikan konsep ijtihad agar ajaran Islam sesuai dengan perkembangan era baru.

${ }^{4}$ Azyumardi Azra, "Cak Nur: Neo-modernisme atau Neo-traditionalisme?" dalam http://www.paramadina-online November 30, 2000, h. 1.
} 
tradisionalis kaya dengan tradisi pemikiran Islam klasik. ${ }^{5}$ Model pemikiran mereka adalah diorientasikan pada pemikiran Islam di masa lampau, dan sangat selektif dalam mengadopsi ide-ide modernis. Nurcholish Madjid sebagai neo-modernis mencoba mengkompromikan kedua model pemikiran tersebut. ${ }^{6}$

Agenda Nurcholish Madjid dalam aspek ini dikembangkan ketika ia kembali dari Chicago. Menurut Azyumardi Azra, Nurcholish Madjid memperkenalkan ide-ide pemikirannya melalui artikel-artikel pada level nasional. Dalam periode ini, ide-idenya tidak hanya didasarkan pada tradisi Islam klasik, tetapi juga intelektualnya berkaitan dengan tantangan modernitas. Ketika ia kembali dari Chicago, model pemikirannya juga sudah berubah. Agenda pemikirannya tidak lagi didasarkan pada upaya membangunkan umat Islam dari tidurnya yang panjang melalui teori "shock therapy" seperti pada tahun 1970-an. ${ }^{7}$

Dalam menganalisis perubahan fokus pemikiran Nurcholish Madjid, Azyumardi Azra berkomentar bahwa ide pemikiran Nurcholish Madjid tidak bisa dikategorikan sebagai neo-modernis, melainkan neo-tradisionalis dengan dasar pertimbangan. Pertama, ide-ide pemikiran Nurcholish Madjid sebagaimana dikemukakan dalam tulisan-tulisannya tentang peradaban Islam memiliki akar tradisi Islam yang kuat. Oleh karena itu, para intelektual yang familiar dengan wacana ini akan beranggapan bahwa tidak ada yang baru dalam pemikiran Nurcholish Madjid. Kedua, Nurcholish Madjid memiliki apresiasi esensial terhadap syariah (hukum Islam), meskipun ia tidak memiliki syariah oriented. Meskipun syariah bukan spesialisasinya, namun Nurcholish Madjid memiliki pengetahuan yang bagus dalam bidang ini. Dalam tulisannya, Nurcholish Madjid menekankan pentingnya syariah dalam kehidupan sehari-hari. Ketiga, dalam aspek esoteris, sangat besar perhatian Nurcholish Madjid dalam bidang tasawuf. Dalam mendiskusikan tasawuf, ia mengeritik Ibnu Taimiyah yang menolak tasawuf dan meminta kepada masyarakat untuk tidak menggeneralisasi tasawuf sebagai aspek yang negatif. Nurcholish Madjid menyatakan bahwa tasawuf sangat penting untuk aspek-

\footnotetext{
${ }^{5}$ Islam traditionalis menggunakan tarekat untuk menyebarkan Islam di Indonesia. Metode ini dikembangkan oleh ulama tradisionalis dalam proses pengajaran melalui pesantren, masjid, dan rumahrumah. Ada banyak macam tarekat di Indonesia, di antaranya Naksyabandiyah, Khalwatiyah Sasiliyah, dan Qadiriyah. Biasanya, nama tarekat meruju pada pendiri tarekat, misalnya Tarekat Qadiriyah didirikan oleh Abdul Qadir Jailani.

${ }^{6}$ Fachry Ali \& Bachtiar Effendy, op. cit., h. 51.

${ }^{7}$ Asyumardi Azra, op. cit., h. 2.
} 
aspek spiritual sebagai kebutuhan hidup saat sekarang dan yang akan datang. ${ }^{8}$ Melalui tasawuf, problem masyarakat akan bisa teratasi yang memiliki kecenderungan pada aspek-aspek materialisme, hedonisme, dan kemiskinan.

Terlepas dari corak pemikiran Nurcholish Madjid dikategorikan sebagai neomodernis atau neo-tradisionalis, dan pemikirannya tentang sekularisme, ia sudah memberi kontribusi berharga bagi pengembangan pemikiran Islam di Indonesia, khususnya dalam aspek filsafat politik.

\section{Filsafat Politik Nurcholish Madjid tentang Sekularisasi}

Isu tentang Islam dan sekular sudah menjadi perdebatan yang cukup panjang di kalangan para intelektual Muslim. John L. Esposito mengatakan bahwa sekular lebih populer dimaknai sebagai pemisahan politik antara agama dan negara. Di beberapa negara modern seperti Prancis dan Turki sering mengkampanyekan anti simbol-simbol agama, dan di bawah rezim "fundamentalisme sekuler" menganggap bahwa penggabungan antara agama dan politik dianggap abnormal, tidak rasional, berbahaya dan ekstrimis. Tokoh-tokoh sekular seringkali mempromosikan gagasan-gagasan seperti toleransi, dan di dalam sebuah masyarakat, pemerintahan tidak didominasi oleh satu ideologi agama. ${ }^{9}$

Tidak bisa dipungkiri bahwa gagasan sekularisasi di Indonesia sulit dilepaskan dari figur Nurcholish Madjid, yang pada tanggal 2 Januari 1970 meluncurkan gagasannya dalam diskusi yang diadakan oleh HMI, PII, GPI, dan Persami, di Menteng Raya 58. Ketika itu, Nurcholish Madjid meluncurkan makalah berjudul "Keharusan Pembaharuan Pemikiran Islam dan Masalah Integrasi Umat”. Gagasan itu kemudian diperkuat lagi dengan pidatonya di Taman Ismail Marzuki Jakarta, pada tanggal 21 Oktober 1992, yang dia beri judul "Beberapa Renungan tentang Kehidupan Keagamaan di Indonesia". Setelah itu, berjubellah para propagandis sekularisasi di Indonesia. ${ }^{10}$

${ }^{8}$ Ibid., h. 4.

${ }^{9}$ John L. Esposito, Rethinking Islam and Secularism-ARDA Guiding Paper Series (State College, PA: The Association of Religion Data Archives at The Pennsylvania State University, 2010), h. 3.

${ }^{10}$ Adnin Armas, "Menelusuri Orisinalitas Gagasan Sekularisasi Nurcholis Madjid" dalam Jurnal Tsaqafah, Vol. 4, No. 2 (1428/2007), h. 1- 14. 
Menurut Nurcholish Madjid, pendekatan dari segi bahasa akan banyak menolong menjelaskan makna suatu istilah. Tentang etimologi sekularisasi, dia berpendapat:

"Kata-kata "sekular" dan "sekularisasi" berasal dari bahasa Barat (Inggris, Belanda dan lain-lain). Sedangkan asal kata-kata itu, sebenarnya, dari bahasa Latin, yaitu saeculum yang artinya zaman sekarang ini. Dan kata-kata saeculum itu sebenarnya adalah salah satu dari dua kata Latin yang berarti dunia. Kata lainnya ialah mundus. Tetapi, jika saeculum adalah kata waktu, maka mundus adalah kata ruang". ${ }^{11}$

Pendapat Nurcholish Madjid mengenai etimologi sekular ini dapat ditelusuri dari pemikiran Harvey Cox, yang pada tahun 1960-an, sudah lebih dahulu menjelaskan secara rinci bahwa istilah Inggris secular berasal dari bahasa Latin saeculum yang berarti zaman sekarang ini (this present age). Ada satu kata lain dalam bahasa Latin yang juga menunjukkan makna dunia yaitu mundus, yang kemudian di Inggriskan menjadi mundane. Kata saeculum lebih menunjukkan masa (time) berbanding mundus yang menunjukkan makna ruang (space). Kata saeculum sepadan dengan kata aeon dalam bahasa Yunani kuno dan kata mundus sepadan dengan kata cosmos dalam bahasa Yunani kuno.

Menurut Harvey Cox, disebabkan kata "dunia" di dalam bahasa Latin memiliki dua istilah yang berbeda, yaitu mundus dan saeculum, maka kata dunia di dalam bahasa Latin menjadi suatu kata yang ambivalen. Ambivalensi kata "dunia" ini, menurut Cox, sebenarnya mengungkapkan problem teologis yang dapat ditelusuri kembali dari perbedaan konsep antara Yunani dan Ibrani. Orang Yunani kuno memandang realitas itu sebagai suatu ruang, sementara dalam bahasa Ibrani, dunia itu menunjukkan suatu masa. Bagi orang Yunani, dunia adalah sebuah ruang, sebuah tempat. Event-event terjadi di dalam (within) dunia, tetapi tiada satu pun yang penting terjadi kepada (to) dunia. Sebaliknya, dalam bahasa Ibrani, esensi dunia adalah sejarah. Peristiwa yang terjadi secara berurutan, bermula dari penciptaan dan menuju kesempurnaan. ${ }^{12}$ Yahudi menganggap bahwa dunia ini diciptakan Tuhan supaya manusia mencintainya dan

\footnotetext{
${ }^{11}$ Nurcholish Madjid, Islam Kemodernan dan Keindonesiaan (Bandung: Mizan, 1987), h. 216.

${ }^{12}$ Harvey Cox, The Secular City: Secularization and Urbanization in Theological Perspective (New York: The Macmillan Company, 1967), h. 16.
} 
membawa kesempurnaan. ${ }^{13}$ Jadi, jika orang Yunani kuno memandang realitas itu menurut ruang, maka orang Yahudi memandang realitas itu menurut masa. Ketegangan konsep antara keduanya kemudian berdampak terhadap teologi Kristen sejak awal pembentukannya.

Salah satu argumentasi Nurcholish Madjid yang terkenal dalam mempertahankan pendapatnya adalah pembedaan antara "sekularisasi" dan "sekularisme". Dalam hal ini, Nurcholish Madjid mengutip pendapat Harvey Cox. ${ }^{14}$ Memang, menurut Cox, sekularisasi mengimplikasikan proses sejarah, hampir pasti tidak mungkin diputar kembali. Masyarakat perlu dibebaskan dari kontrol agama dan pandangan hidup metafisik yang tertutup (closed metaphysical worldviews). Jadi, intinya, sekularisasi adalah perkembangan yang membebaskan (a liberating development). Sebaliknya, sekularisme adalah nama sebuah ideologi. Ia adalah sebuah pandangan hidup baru yang tertutup yang fungsinya sangat mirip dengan agama. Selain itu, lanjut Cox, sekularisasi itu berakar dari kepercayaan Bible. Pada taraf tertentu, ia adalah hasil otentik dari implikasi kepercayaan Bible terhadap sejarah Barat. Oleh sebab itu, sekularisasi berbeda dengan sekularisme - yaitu ideologi(isme) yang tertutup. Bagi Cox, sekularisme membahayakan keterbukaan dan kebebasan yang dihasilkan oleh sekularisasi. Oleh sebab itu, sekularisme harus diawasi, diperiksa dan dicegah untuk menjadi ideologi negara. ${ }^{15}$

Nurcholish Madjid selanjutnya menjelaskan bahwa perbedaan antara "sekularisasi" dan "sekularisme" semakin jelas jika dianalogikan dengan perbedaan antara rasionalisasi dan rasionalisme. Seorang Muslim harus bersikap rasional, tetapi tidak boleh menjadi pendukung rasionalisme. Rasionalitas adalah suatu metode guna memperoleh pengertian dan penilaian yang tepat tentang suatu masalah dan pemecahannya. Rasionalisasi adalah proses penggunaan metode itu. Analoginya, lanjut Nurcholish Madjid, sekularisasi tanpa sekularisme, yaitu proses penduniawian tanpa paham keduniawian, bukan saja mungkin, bahkan telah terjadi dan terus akan terjadi dalam sejarah. Sekularisasi tanpa sekularisme adalah sekularisasi terbatas dan dengan koreksi. Pembatasan dan koreksi itu diberikan oleh kepercayaan akan adanya Hari

\footnotetext{
${ }^{13}$ Martin E. Marty, Does Secular Theology Have a Future? The Great Ideas Today (Chicago: Encyclopedia Britanica Inc., 1967).

${ }^{14}$ Harvey Cox, op.cit., h. 18.

${ }^{15}$ Ibid.
} 
Kemudian dan prinsip Ketuhanan. Sekularisasi adalah keharusan bagi setiap umat beragama, khususnya ummat Islam. ${ }^{16}$

Dalam menggulirkan filsafat sekularisasinya, Nurcholishh mencari justifikasi dari ajaran-ajaran Islam. Ia misalnya menyatakan gagasan sekularisasi dapat dijustifikasi dari dua kalimat syahadat, yang mengandung negasi dan afirmasi. Menurut interpretasinya, kalimat syahadat menunjukkan bahwa manusia bebas dari berbagai jenis kepercayaan kepada tuhan-tuhan yang selama ini dianut, kemudian mengukuhkan kepercayaan kepada Tuhan yang sebenarnya. Islam dengan ajaran Tauhidnya yang tidak kenal kompromi itu, telah mengikis habis kepercayaan animisme. Ini bermakna dengan tauhid, terjadi proses sekularisasi besar-besaran pada diri seorang Animis. Manusia ditunjuk sebagai khalifah Tuhan di bumi karena manusia memiliki intelektualitas, akal pikiran, atau rasion. Dengan rasion inilah, manusia mengembangkan diri dan kehidupannya di dunia ini. Oleh karena itu terdapat konsistensi antara sekularisasi dan rasionalisasi Kemudian, terdapat pula konsistensi antara rasionalisasi dan desakralisasi. Nurcholish Madjid melanjutkan argumentasinya di dalam Islam ada konsep "Hari Dunia" dan "Hari Agama". Hari Agama ialah masa di mana hukum-hukum yang mengatur hubungan antara manusia tidak berlaku lagi, sedangkan yang berlaku ialah hubungan antara manusia dan Tuhan. Sebaliknya, pada Hari Dunia yang sekarang kita jalani ini, belum berlaku hukum-hukum akhirat. Hukum yang mengatur perikehidupan ialah hukum-hukum kemasyarakatan manusia. ${ }^{17}$

Nurcholish Madjid melanjutkan argumentasinya, bahwa kalimat Basmallah (Atas nama Tuhan), juga menunjukkan bahwa manusia adalah Khalifah Tuhan di atas bumi. Selain itu, al-Rahman menunjukkan sifat kasih Tuhan di dunia ini (menurut ukuran-ukuran duniawi), sedangkan al-Rahim menunjukkan sifat Kasih itu di akhirat (menurut norma-norma $u k h r a w i)$. Penghayatan nilai/spiritual keagamaan bukanlah hasil kegiatan yang serba rasionalistis. Demikian pula sebaliknya, masalah-masalah duniawi tidak dapat didekati dengan metode spiritualistis. Keduanya mempunyai bidang yang berbeda, meskipun antara iman dan ilmu itu terdapat pertalian yang erat. ${ }^{18}$

\footnotetext{
${ }^{16}$ Adnin Armas, op.cit., h. 3.

${ }^{17}$ Ibid., h.4.

${ }^{18}$ Ibid.
} 


\section{Filsafat Politik Nurcholish Madjid tentang Civil Society}

Ide Nurcholish Madjid tentang civil society didasarkan atas masyarakat Islam yang dibangun oleh Nabi Muhammad di kota Madinah pada tahun 570 M. Meskipun ide Nurcholish Majid tentang negara menganut sistem sekularistik, namun idenya tentang civil society disandarkan pada konsep masyarakat madani sebagaimana yang pernah terjadi pada masa Rasulullah. Sementara itu, konsep negara dalam pandangan Iqbal merujuk kepada konsep negara Madinah.

Nama Madinah memiliki dua arti, yaitu sebagai "kota", dan sebagai "peradaban." Sebelum Nabi Muhammad pindah ke madinah, kota tersebut dikenal sebagai Yastrib. Menurut Nurcholish Madjid, Nabi Muhammad mengubah nama kota itu karena ia ingin membangun peradaban Islam di kota tersebut. Prinsip-prinsip civil society dimuat dalam "Piagam Madinah," dokumen yang memuat konsep-konsep agama, ekonomi, tanggung jawab sosial, politik dan pertahanan. ${ }^{19}$ Oleh karena itu, Nurcholish Madjid memberi interpretasi kontemporer terhadap karakteristik model civil society yang telah dibangun oleh Nabi Muhammad. Aspek yang ditekankan dalam konsep civil society meliputi aspek egalitarian, respek kepada orang lain, berpartisipasi aktif dalam masyarakat, berpegang kepada hukum dan keadilan, toleransi dan pluralisme, dan deliberasi. Nurcholish Madjid mengatakan bahwa untuk menciptakan sebuah civil society, kehidupan masyarakat mensyaratkan dimensi spiritual dan sikap yang bagus terhadap masyarakat lain. Nabi Muhammad memutuskan untuk mengubah nama kota Madinah adalah diinterpretasikan oleh Nurcholish Madjid sebagai "sebuah proklamasi atau sebuah deklarasi" yang di dalam tempat baru tersebut Nabi Muhammad bermaksud menciptakan sebuah masyarakat teratur. Oleh karena itu, konsep madinah adalah sebuah paradigma baru bagi peradaban masyarakat Islam yang dibangun di atas sebuah kewajiban dan kesadaran universal untuk mengikuti regulasi-regulasi dan hukum-hukum. ${ }^{20}$

Dalam kaitannya dengan hukum dan keadilan, Nabi Muhammad sangat respek kepada setiap orang tanpa memandang status sosial. Nabi Muhammad menyatakan bahwa kehancuran negara-negara di masa lampau terjadi jika status sosial yang tinggi

\footnotetext{
${ }^{19}$ Nurcholish Madjid, "Islam dan Politik: Studi atas Prinsip-Prinsip Hukum dan Keadilan" dalam Jurnal Pemikiran Islam Paramadina, Vol. 1 (2000), h. 3

${ }^{20}$ Ibid.
} 
tersangkut masalah kriminal namun tidak tersentuh hukum, sementara status sosial yang rendah yang melakukan kriminal yang sama harus dihukum. Masyarakat memiliki perasaan yang kuat terhadap prinsip kesamaan dan egalitarian sebagai ciptaan Tuhan. Menurut Nurcholish Madjid, untuk membawa kontrol sosial dalam realitas, setiap orang harus harus membuka diri kepada masyarakat sebab mereka umumnya memiliki potensi berbuat kesalahan (Q.S. 3: 28). Oleh karena itu, setiap orang memiliki hak untuk mengekspresikan ide-ide mereka, sebab mereka memiliki sebuah tanggungjawab untuk mendengar opini orang lain. ${ }^{21}$

Civil society dalam pandangan Nurcholish Madjid adalah sebuah sosial demokrasi yang memiliki sebuah kontrak sosial yang didasarkan pada deliberasi. Deliberasi berarti sebuah interpretasi positif dari setiap orang untuk memahami orang lain dengan sebuah kesadaran atas keanekaragaman masyarakat. Dengan kata lain, deliberasi adalah sebuah hubungan interaktif untuk mengingatkan kita bahwa kebaikan dan kebenaran dapat memecahkan problem sosial. Dalam proses deliberasi, interaksi sosial muncul didasarkan atas toleransi dan pluralisme.

Sangat jelas bahwa ide Nurcholish Madjid tentang civil society nampaknya didasarkan atas argumentasi normatif. Nurcholish Madjid menekankan keperluan nilainilai humanis yang didasarkan atas agama dalam kaitannya dengan eksistensi dan pengembangan civil society. Sebagai entitas sosial, civil society adalah ekspresi kolektif ide dan sikap manusia atas dasar moralitas agama. Nurcholish Madjid meneliti dengan cermat demokrasi dengan mengatakan bahwa hanya demokrasi satu-satunya fondasi membangun civil society. Ia juga mengatakan bahwa moral agama jauh lebih penting. Jika civil society dipahami hanya melalui kriteria demokrasi, maka penetapan institusiinstitusi sosial yang mandiri akan mengalami bencana ketika seluruh masyarakat tidak menunjukkan sikap toleransi, seperti hubungan antara sebuah agama atau sebuah suku. Oleh karena itu, civil society perlu merefleksikan elemen-elemen masyarakat. Seluruh masyarakat dan kelompok-kelompok harus direpresentasikan agar saling menghormati perbedaan, tanpa menghancurkan integritas negara.

Aspek terpenting ketiga adalah ide Nurcholish Madjid tentang modernisme Islam sebagai reaksi terhadap kebijakan modernisasi pemerintah Indonesia pada masa

\footnotetext{
${ }^{21}$ Nurcholish Madjid, "Agama dan Sosial” dalam Ulumul Qur'an: Jurnal Budaya dan Peradaban, No. 1 (1989), h. 53.
} 
Orde Baru. Strategi pengembangan yang dirancang oleh Suharto sangat berbeda dengan masa Orde Lama. ${ }^{22}$ Strategi Orde Baru menekankan sebuah pendekatan pragmatis untuk memecahkan persoalan-persoalan di Indonesia. Melalui institusi Golkar, programprogram Orde Baru tentang pengembangan materi dan modernisasi dengan cepat diimplementasikan. ${ }^{23}$

Munculnya satu problem pokok berkaitan dengan isu modernisasi adalah bagaimana masyarakat Islam menguji "modernisasi" dari pandangan ajaran Islam? Apakah program-program modernisasi dan nasionalitas didasarkan atas strategi pengembangan memiliki dampak negatif bagi umat Islam?. Marjinalisasi ekonomi dan politik dari banyak umat Islam di Indonesia disebabkan oleh sebuah reaksi terhadap efek modernisasi dan sekularisme. ${ }^{24}$

Menurut FachryAli dan Bahtiar Efendy, realitas adalah efek marginalisasi politik dan ekonomi yang menstimulasi konflik agama dan politik. Peranan intelektual muslim adalah untuk mempromosikan inklusi filsafat Islam dalam strategi modernisasi yang dihasilkan dalam marjinalisasi. Intelektual muslim harus menjelaskan kepada umat Islam Indonesia bahwa mereka memiliki hak yang sama untuk berpartisipasi disetiap proses pembangunan nasional. ${ }^{25}$

Respon intelektual dimulai dengan relasi modernisasi dan Islam dan implikasinya bagi umat Islam. Nurcholish Madjid mengatakan bahwa modernisasi identik dengan rasionalisasi. Modernisasi adalah sebuah proses untuk menghapus pola pemikiran irasional dan menggantikannya dengan sistem pemikiran rasional yang baru. Proses tersebut didasarkan atas aplikasi sains dan teknologi. Sains adalah obyektivitas manusia yang komprehensif dari hukum-hukum alam, sehingga implementasinya memiliki karakteristik rasional dan modern. ${ }^{26}$

Penjelasan Nurcholish Madjid cenderung menerima modernisasi, sebab ia bekerja dan mensyaratkan pemikiran yang sesuai dengan hukum alam. Karakteristik modernisasi adalah orientasi ilmiah dan memiliki sebuah sikap loyalitas universal terhadap pembangunan. Selain itu, Al-Quran sebagai jalan hidup umat Islam sesuai

\footnotetext{
${ }^{22}$ Herbert Feith, "Soeharto's Search for Political Format" dalam Indonesia 6 (1968), h. 88-105.

${ }^{23}$ Kamal Hassan, Muslim Intellectual Response to New Order Modernization in Indonesia (Malaysia: Kuala Lumpur language Council, 1990), h. 1.

${ }^{24}$ Fachry Ali \& Bachtiar Effendy, op. cit., h. 109.

${ }^{25}$ Ibid.

${ }^{26}$ Ibid., h. 115.
} 
dengan modernisasi. Apresiasi Nurcholish Madjid tentang modernisasi, nampaknya ia masih berhati-hati dalam responnya terhadap pengembangan modernisasi di Indonesia yang telah menghasilkan problem-problem sosial yang jelas.

Nurcholish Madjid dengan hati-hati mencatat bahwa modernisasi bukan westernisasi. Jika modernisasi sama dengan westernisasi, termasuk elemen-elemen sekularisme, ajaran Islam menolaknya. Secara umum sekularisasi cenderung memisahkan gereja dengan negara. Sebagaimana disebutkan sebelumnya, Islam tidak memisahkan atmosfer politik dan agama. Islam dengan dirinya atas kenyataan bahwa Tuhan mengintervensi seluruh aktivitas manusia.

Berkaitan dengan idenya tentang Islam dan ideologi, Nurcholish Madjid berkomentar bahwa ada pemisahan antara Islam dan ideologi yang dibatasi oleh ruang dan waktu. Meskipun ideologi melibatkan aspek-aspek yang luas dan kompleks, namun memiliki sebuah makna positif terhadap Islam, di mana Islam sebagai ideologi harus dimunculkan karakteristiknya sebagai agama yang memiliki kesamaan dengan ideologi lain. ${ }^{27}$ Dalam statemen ini, Nurcholish Madjid meminta umat Islam Indonesia untuk mereview proses ideologi politik Islam dari sejak awal kemerdekaan Indonesia hingga masa Orde Baru. Dia berargumentasi bahwa studi kritis atas sumber-sumber keagamaan sangat diperlukan, bukan sekedar respek tetapi juga mengkritisi asal mula budaya sejak generasi awal dan memahami setiap perkembangan periode. ${ }^{28}$ Nurcholish Madjid berargumentasi bahwa ideologi Islam masa silam sangat kuat perlu disesuaikan dengan kondisi masyarakat Islam Indonesia secara universal. Karenanya, ketika Nurcholish Madjid mendiskusikan antara Islam dan Orde Baru, ia menekankan bahwa pembangunan sosial politik tidak bisa dilaksanakan dalam terma-terma absolut, tetapi harus didemonstrasikan dalam terma-terma relatif. ${ }^{29}$

Meskipun pemikiran Nurcholish dianggap kontroversial dan bersifat liberal, namun dalam analisis Mohammed Arkoun menilai bahwa pemikir Islam dewasa ini yang memiliki kecenderungan untuk mencontoh masyarakat Madinah yang pernah dibangun Rasulullah di era sekarang ini dapat dikategorikan sebagai pemikir

\footnotetext{
${ }^{27}$ Nurcholish Madjid, "The Aspiration of Our Politics" dalam Basco Carvallo Dazrizal (ed.), The Aspiration of Islam Indonesia (Jakarta: Leppemas, 1983), h. 4.

${ }^{28}$ Ibid., h. 4.

${ }^{29}$ Ibid., h. 5.
} 
fundamentalis. ${ }^{30}$ Sementara itu, filsafat politik Nurcholish Madjid tentang civil society diterjemahkan kedalam bahasa Indonesia menjadi masyarakat madani merujuk kepada tatanan masyarakat yang dibangun oleh Rasulullah di Madinah. Klaim dari teori Arkoun kepada Nurcholish Madjid tidak bisa dikategorikan sebagai pemikir fundamental tanpa memahami pemikiran politik Nurcholish Madjid secara utuh. Nurcholish Madjid adalah seorang pemikir Islam yang moderat bahkan cenderung liberal dalam mengemukakan gagasan-gagasannya bagi kemajuan umat Islam di Indonesia.

Filsafat politik Nurcholish Madjid terkait dengan konsep sekularisasinya keluar dari mainstream pemahamam umum selama ini yang dianggap sebagai proses pemisahan antara aspek politik dengan agama. Sementara penjelasan Nurcholish Madjid di atas memaknainya sebagai proses peniadaan tuhan-tuhan menuju kepada pengakuan kepada Tuhan yang sesungguhnya sebagai pengejawantahan dari kalimat laa ilaha illallah. Tujuan utama dari filsafat politik ini agar umat Islam dapat keluar dari belenggu kejumudan sehingga dapat mengejar ketertinggal dari imu pengetahuan dan teknologi.

\section{Penutup}

Dari uraian di atas dapat dipahami bahwa Nurcholish Madjid memiliki ide pemikiran yang cukup kontroversial di kalangan cendekiawan Muslim di Indonesia. Ia banyak menformulasikan pemikiran filsafat untuk kemajuan Islam yang tertinggal akibat kejumudan pemikiran dan ketertinggalan masyarakat Islam dibanding negara Barat yang menjajah. Nurcholish Madjid banyak menggali khazanah pemikiran intelektual klasik, kemudian diinterpretasikan sesuai dengan perkembangan zaman demi kemajuan negara dan masyarakat Islam. Ia menyadari bahwa negara maupun masyarakat Islam sangat jauh tertinggal dalam aspek ilmu pengetahuan dan teknologi dibanding dengan negara-negara Barat. Yang terpenting adalah pembaharuan pemikiran Nurcholish Madjid yang dalam tataran ide diimplementasikan dalam bentuk aksi oleh banyak kalangan generasi muda, khususnya dalam aspek filsafat politik, terkait dengan konsep etika politik, negara, dan civil society.

${ }^{30}$ Mohammed Arkoun, “Metode Kritik Akal Islam” dalam Jurnal Ulumul Qur'an, Vol. V, No 6 (1994), h. 157. 
Dalam pemikiran tentang sekularisasi, yang diinginkan Nurcholish Madjid adalah bagaimana merombak pola pikir masyarakat Islam agar bisa maju. Ia beranggapan bahwa kemajuan umat Islam bisa dicapai memalui sikap akomodatif dengan Barat. Aspek menarik lainnya adalah pemikirannya tentang konsep civil society. Nurcholish Majid menggunakan istilah masyarakat madani, merujuk kepada kondisi masyarakat yang telah dibangun oleh Nabi Muhammad di Madina. Dalam kaitan ini, Nurcholish Madjid menginginkan agar masyarakat Indonesia dapat memahami konsep civil society agar mereka dapat bersikap egalitarian, respek kepada orang lain, berpartisipasi aktif dalam masyarakat, berpegang kepada hukum dan keadilan, toleransi dan deliberasi.

\section{DAFTAR PUSTAKA}

Ali, Fachry \& Bachtiar Effendy. Merambah Jalan Baru Islam: Rekonstruksi Pemikiran Islam Indonesia Masa Orde Baru. Bandung: Mizan, 1990.

Arkoun, Mohammed. "Metode Kritik Akal Islam” dalam Jurnal Ulumul Qur'an, Vol. V, No 6 (1994).

Armas, Adnin. "Menelusuri Orisinalitas Gagasan Sekularisasi Nurcholis Madjid" dalam Jurnal Tsaqafah, Vol. 4, No. 2 (1428/2007), h. 1- 14.

Azra, Azyumardi. "Cak Nur: Neo-modernisme atau Neo-traditionalisme?" dalam http://www.paramadina-online November 30, 2000.

Cox, Harvey. The Secular City: Secularization and Urbanization in Theological Perspective. New York: The Macmillan Company, 1967.

Esposito, John L. Rethinking Islam and Secularism-ARDA Guiding Paper Series. State College, PA: The Association of Religion Data Archives at The Pennsylvania State University, 2010.

Feith, Herbert. "Soeharto's Search for Political Format” dalam Indonesia 6 (1968), h. 88-105.

Hassan, Kamal. Muslim Intellectual Response to New Order Modernization in Indonesia. Malaysia: Kuala Lumpur language Council, 1990.

Madjid, Nurcholish. "Agama dan Sosial” dalam Ulumul Qur'an: Jurnal Budaya dan Peradaban, No. 1 (1989). 
--------. "Islam dan Politik: Studi atas Prinsip-Prinsip Hukum dan Keadilan" dalam Jurnal Pemikiran Islam Paramadina, Vol. 1 (2000).

--------. "The Aspiration of Our Politics" dalam Basco Carvallo Dazrizal (ed.). The Aspiration of Islam Indonesia. Jakarta: Leppemas, 1983.

--------. Islam Kemodernan dan Keindonesiaan. Bandung: Mizan, 1987.

Marty, Martin E. Does Secular Theology Have a Future? The Great Ideas Today. Chicago: Encyclopedia Britanica Inc., 1967.

Sulbi. "Islam Kemodernan dan Keadilan Sosial dalam Pandangan Nurcholish Madjid" dalam Palita: Journal of Social Religion Research, Vol. 6, No. 1 (2021), h. 124. 